
Dmytro DUBOV

The National Institute for Strategic Studies, Kiyv, Ukraine

DOI : $10.14746 /$ ps.2020.1.2 https://orcid.org/0000-0001-9728-369X

\section{Anastasiia BAROVSKA}

The National Institute for Strategic Studies, Kiyv, Ukraine https://orcid.org/0000-0001-9010-488X

\section{Iryna KORETSKA}

The National Institute for Strategic Studies, Kiyv, Ukraine https://orcid.org/0000-0003-0728-3608

\section{"ACTIVE MEASURES" OF THE USSR AGAINST THE USA: OLD SOVIET GAMES IN THE NEW GEOPOLITICAL REALITY}

With the outbreak of military actions in Ukraine, the concept of "hybrid war" has been in use more and more frequently. At the same time, this concept remains rather debatable and is often criticized, mainly because there is no exact paradigm approach attached to it.

Criticism mostly concerns the "novelty" aspect of the hybrid war phenomenon. At first glance, this criticism is fair enough, since indeed, most of the tools and methods applied in the current hybrid war have been introduced and commonly used much earlier.

This conformity of the set of pressure methods applied against the other state with the general goal is the main characteristic of "active measures." This notion is also not new, it goes back to the times of Soviet intelligence services, when deceptive information, agents of influence, quasi-civil organization, and information pressure became quite common tools.

And today, all these practices are again on the agenda. Curiously, very often their form is exactly the same.

Until 2014 Russia's “active measures" were only a simple tool of permanent influence on Ukraine, and total disregard of these tools applied on the country ended up in a hybrid war. Today, the Russian Federation is also using this tool on a larger scale against several democratic countries at the same time. Most of these operations relate to Western democracies (the U.S., UK, France, Greece, Germany), while some elements of modern "active measures" are traced in operations against African countries (for example, researchers note actions in the Central African Republic, Libya, Sudan, Madagascar) (Badanin, 2019).

All of the above forces the researchers to pay significantly more attention to the idea of "active measures." Mostly because by far the majority of the related methods and tools are still being used today in the ongoing hybrid war. 
When it comes to "active measures," it is neither about activities, certain politicians and/or intelligence officers nor about situational (ad-hoc) use of methods; this refers to the whole system of practices implemented within the framework of a certain political strategic idea. In accordance with the Cold War concept, the achievement of this strategic idea takes place without the direct use of military power. Those were "active measures" that made the deceptive information, agents of influence, quasi-civil organization, and information pressure the realities of the Cold War confrontation.

What exactly was understood by the concept of "active measures"? What were the methods of these activities according to research papers? How "active measures" are related to the concept of hybrid warfare? This study aims to provide answers to these and other related questions.

The key sources for our research are the unclassified documents of the CIA dated from 1947 to 1989. These are mostly declassified CIA quarterly reports on Soviet activities (including "active measures"), texts of speeches by heads of special services on the USSR's subversive activities against the Western world, correspondence between the CIA, FBI and Congressional committees on Russian subversive activities, reports from other special services (such as the FBI) on detected cases of subversion, reports and investigations carried out either by the CIA or at the request of the CIA on the practice of Soviet subversive activities, other materials that have not been publicly available so far. Other official materials of the U.S. have been also used along with research studies. This enabled us to consider "active measures" and ways of counteracting them in a much wider context.

While the abovementioned official documents were aimed at recording various "active measures" and ways to protect against them and counter them, the research attempted to classify "active measures," identify mechanisms for their implementation and management, as well as assess the goals and results of their application. The use of both sets of documents allowed us, in particular, to identify certain "gaps" in the previously proposed classifications and to compare Russia's goals with the goals set by the Soviet Union, using "active measures" to achieve them. Based on that the bodies involved in the development and implementation of "active measures" in the USSR de facto did not cease to exist in Russia, and Russia itself is currently in a phase of confrontation with almost all Western democracies and preaches "different" ways of waging modern wars, the authors suggested that there is a connection between the "active measures" of the Cold War and modern hybrid actions of the Russian Federation aimed at achieving its strategic goals.

\section{WHAT DOES THE CONCEPT OF “ACTIVE MEASURES” MEAN?}

As the main object of the "active measures" impact was the United States, it is natural that the American researchers suggested the most fruitful studies aiming to find out the essence, effects and the potential of "active measures" in general.

American researcher Stephanie K. Whittle (Whittle, 2015) posits that the origin of the concept of "active measures" dates back to the times when the Comintern" stat-

${ }^{1}$ The Communist International (Comintern), known also as the Third International (1919-1943), was an international organization that advocated world communism in opposing reformist socialism 
ute was approved (Ustav..., 1921). This document established as its long-term vision "the struggle by all available means, including armed force, for the overthrow of the international bourgeoisie and the creation of an international Soviet republic," which was supposed to be the transition stage until the absolute destruction of the state (Ustav..., 1921). Other researchers (Bass, 1999) deem that the concept "active measures" emerged slightly later, in the 1920s, and this was directly connected with the establishment of the so-called Cheka ${ }^{2}$ - the All-Russian Extraordinary Commission for Combating Counter-Revolution, Speculation and Sabotage. The Cheka, founded by Felix Dzerzhinsky, is often considered (which is quite appropriately) the direct predecessor of the KGB.

However, the attention of American researchers and professional communities was drawn to the topic of "active measures" much later, starting in 1984.

Since then, the essence and methods of "active measures" have been studied by well-known think tanks such as the Heritage Foundation (Manfred, 1984), Hoover Institution on War, Revolution and Peace (Memorandum, 1985), specialized government organizations (eg the CIA (Memo, 1984) and the FBI (Young, 1987) and individual researchers. The first studies of the concept of "active measures" is distinguished by neglecting the terminology. For example, Dennis Kux suggested considering the Soviet practices of implementation of "active measures," differentiating between "white," "gray" and "black" activity in the interests of foreign policy.

Apart from Dennis Kux, the following authors are worth mentioning among the researchers of the concept of "active measures" and various aspects of their implementation: Lawrence B. Sulc - the former CIA officer with over 20 years of experience and later the assistant at the Department of State (Sulc, 1985a; Sulc, 1985b), Charles M. Lichenstein (Lichenstein, 1985), Juliana Geran Pilon (Pilon, 1986), Keenan Harry Hohol (Hohol, 1988). Modern researchers also study "active measures," the problems of their classification and the possibility of implementation in current realities (Darczewska, Żochowski, 2017). American researchers have devoted a lot of papers to attempts to figure out the organizational mechanism for initiating, developing and implementing "active measures" or their certain aspects.

The major findings of these studies are:

- the scale of pervasion of "active measures" is large, the fields are diverse;

- there are many methods of "active measures," but at the same time, there are the most frequently used ones;

- the use of "active measures" is controlled from a singlecenter;

- national and community resilience to influences is essential for counteracting "active measures."

Along with scientists' research efforts, practical professionals tried to formulate the most exact definition of "active measures" and clarify in real time what they actually

of the Second International. Vladimir Lenin was the founder of this organization. Stalin, head of the Soviet Union, dissolved the Comintern in 1943 to avoid antagonizing his allies in the latter years of World War II, the United States and the United Kingdom.

2 Vserossiyskaya chrezvychaynaya komissiya po borbe s kontrrevolyutsiyey $i$ sabotazhem pri Sovete narodnykh komisarov RSFSR, abbreviated VChK and commonly known as Cheka was the first in the succession of Soviet secret-police organizations. 
are. The most famous and the first document that demonstrates practitioners' efforts to define "active measures" is the "Long Telegram" (Telegram..., 1946).

Definitions of "active measures" and attempts to classify their methods are also made in such documents as: Special Report to the U.S. Department of State "Soviet active measures": forgery, disinformation, political operations" (Special Report, 1981), Public diplomacy document "Soviet military power" (Report, 1982), National Security Study Directive 2/82 (NSSD 2/82, 1982) and also "Definitions for terms of reference and outline for NSSD 2/82" (Definitions for terms, 1982), reports and other CIA documents (HPSCI briefing, 1983; Background Briefing..., 1985) and FBI documents (Young, 1987).

From the above material, it is clear that attempts to determine the notion of "active measures" were carried out in two major directions: 1 ) through a combination of methods and tools applied; 2) through the description of activities' aims.

Particular combinations of methods mostly included the methods and tools described in the "Long Telegram," however, this list may have been changed/extended from definition to definition.

The second variant of defining "active measures" that is, interpretation through aims, also had two major approaches within:

- Broad aims (for example, when "active measures" are interpreted as "exercising influence on the policies of other states with the use of means, different from spying and counterintelligence");

- Specified and detailed aims (for example, "isolating the object of attack from foreign partners, influence on public opinion").

Despite all efforts to reveal Soviet "active measures," the very notion of "active measures" is not yet fully conceptualized till nowadays. Therefore, we would like to suggest our own definition which is more appropriate for the current context, for practical application to contemporary (in particular - Ukrainian) realia as well as for more general estimation of today's Russian "active measures" potential. Thus:

"Active measures" stand for the activities aimed at the achievement of external and internal political aims of the state as the subject of influence; these activities are implemented to exert negative influence on the public opinion in the state which is the object of influence and to change the policies and activities of the government in this state, erode trust to its political leaders and institutions as well as to disorient the global public opinion in its assessments of this state's policies and activities.

\section{METHODS OF "ACTIVE MEASURES"}

In general, research papers provide different classifications of "active measures," but they do not consider "active measures" as a necessary combination of a goal and a way to achieve this goal, despite that the goal of "active measures" is mentioned in many papers. In particular, Jolanta Darczewska and Piotr Żochowski determine the coordination of "active measures" and their focus on the broad ideological expansion of the USSR (Darczewska, Żochowski, 2017). 
In our study, we tried to derive the "formula" of "active measures" based on two statements: 1) "active measures" of the USSR against the United States during the Cold War was the influence, subordinated to a specific goal and idea; 2) the implementation of this idea was carried out by specific actions by executors. Such specific actions were called "active measures" methods. Therefore, we claim that the "formula" of "active measures" is: goal + method. In fact, the methods of "active measures" are given as units of classification of "active measures" in the works of various authors. Below we provide the main methods of "active measures" and the authors' reflections on the completeness of the proposed classifications and the need to mention certain methods.

Also, we should notice that such a variety of methods has been preconditioned not as much by the variety of authors' views on the essence of "active measures," but rather by the objective complexity of even theoretical determination of all these types of activities. In essence, this term embodied a range of activities limited only by the imagination and creativity of the KGB's half-million officers and could have included anything from simple propaganda to kidnapping, murder, drug trafficking, and illicit support of terrorism (Abrams, 2016).

In his book "Active measures, quiet war and two socialist revolutions" L. Sulc expands the list of possible actions which, in his opinion, can be classified as "active measures," including, inter alia, the following methods: the use of political parties, insurgent groups and front organizations; international front groups and non-government organizations; agents of influence; acts of terror; the so-called "wet affairs" (that is, killings); deception acts; forgery cases; the intrusion of the idea of the existence of two superpowers; the so-called "maskirovka" (which includes primarily military and political deception); disinformation; cultural warfare; using foreign broadcasting; sports events.

In his other book "The KGB and the United Nations: Soviet subversion and intelligence operations in the United Nations Secretariat" (Sulc, 1985b) L. Sulc noted that the major types of activities to exert the influence in this regard included: editing of conference materials; control over the flow of news and other important information; influencing the delegates which were seeking advice from the Secretariat; direct help to Soviet diplomats in their work; supporting Soviet propaganda; arranging documents for the UN Secretary -General so that to make references favorable for the Soviet Union; embedding pro-Soviet documents into the UN records so that later Soviet propaganda was able to refer to the UN documents as eligible grounding; placement of Soviet personnel in the UN offices responsible for non-governmental organizations (NGOs) and Soviet front groups which, in turn, later influenced the nature of the UN debates. These and the related issues have been also thoroughly studied in the work by Juliana Geran Pilon “At the U.N., Soviet Fronts Pose As Nongovernmental Organizations” (Pilon, 1986).

Classical intelligence operations within the UN has been always performed in several rather traditional directions: collecting information on the UN activities, especially early warnings of any possible UN actions; gathering information on third countries; spotting, assessing and recruiting agents, both UN employees with whom agents came in contact and other citizens of the countries to which they were assigned and/or to which they frequently traveled; supporting intelligence operations in a host country. 
In 1988 yet another fundamental study was published - "Soviet Communication: Active Measures and Information Management" by Keenan Harry Hohol (Hohol, 1988). This study analyzed in detail the overall context of implementing "active measures" along with the specific mechanisms used for this end. K. H. Hohol, through his thorough analysis of the key techniques, arrived at quite meaningful conclusions concerning the application of specific methods in the course of "active measures" taken, namely on forgeries of documents. In particular, he marked out the obvious cyclicity of persistence of the KGB (or those smaller structures which were at some point responsible for the measures): in case some individual operations failed to achieve the desired result on the first try, this did not deter the Soviets from attempting the operation again. Many forgeries, rumors, and clandestinely placed press items strained credulity at first attempt, but replaying the same was often quite successful, thus making these distortions more acceptable.

In his opinion, all Soviet "active measures" rested on a certain, rather limited set of special methods (K. H. Hohol called them "classical"): disinformation; manipulations and control over foreign media; forgery documents; agents of influence; international front organizations; communist parties and their branches abroad; friendship and cultural societies; clandestine radio broadcasting.

Stephanie K. Whittle (Whittle, 2015) suggests a systematic presentation of methods of "active measures." This particular scheme can still be considered as the "core" one while studying the overall system of "active measures" used by the USSR.

Generalization of the most typical methods of implementing "active measures" against the Western world during the 1980s enables us to compile the following list: use of the agents of influence (in all spheres and fields); preparation and dissemination of disinformation; use of political parties (most frequently - various leftist ones); establishment, engagement and support of international movements and organizations as well as manipulations with their activities; front organizations; media manipulations (including in own ones); dissemination of fake stories through media of the Third World countries; clandestine broadcasting; blackmail; political influence; sending military advisors to certain countries; training and supporting insurgent and terrorist groups; economic aid; spreading rumors; providing misleading information to politicians and journalists; spreading fake documents; political assassinations; cultural standoff; using foreign media for own purposes; using sport events; organization and support of "peaceful" demonstrations; active use of the UN and other international structures; use of religious organizations.

\section{“ACTIVE MEASURES” OF THE USSR AND RUSSIA'S HYBRID WAR: CASES}

We are still facing quite a range of consequences from Soviet large-scale operations implemented by the KGB at the international level. Many of these fake news and misconceptions are still shaping the mass consciousness in many countries (the most common examples are, probably, "CIA responsibility for the assassination of Olof Palme" or "CIA created the AIDS virus in its secret labs"). 
Experience and tools used for decades in the Soviet Union are now at Russia's full disposal. Strictly speaking, the pause in the use of "active measures" lasted around 15 years, and the Russians returned to these practices already in 2007-2008.

Russian Federation today is using previously approved (and many times already mentioned throughout the text) tools and methods, including agents of influence, deception and use of media (own and foreign ones), front organizations etc.; however, most of these methods under today's conditions are getting new contents and meaning.

At the same time, the negative influence on the population's attitude to the acting political authorities, political institutes in general as well as political efforts in the fields of economy, diplomacy and military affairs remains unchanged.

\section{Election interference}

One striking example of the use of "active measures" during the Cold War is the re-election campaign of Ronald Reagan in 1980. Such methods as misinformation and fake news, psychological pressure and threats were employed. According to extensive notes made by Vasiliy Mitrokhin, a high-ranking KGB officer and archivist who later defected to Great Britain, Soviet intelligence tried to infiltrate the headquarters of the Republican and Democratic National Committees, popularize the slogan "Reagan Means War!", and discredit the President as being corrupt and as a supposed McCarthyism supporter (Osnos, Remnick, Yaffa, 2017).

The Soviet press compared the Reagan Administration to the leaders of Nazi Germany and Reagan himself was portrayed as the crony of a top Nazi. However, the Soviet toolkit was not limited to only these actions. Moscow was ready to use any topic which potentially could have been damaging to Reagan's election campaign. The final aim of this very intensive campaign on discrimination was to show the American (as well as Soviet and European) citizens that the Soviet Union simply could not deal with such a "monster" as Ronald Reagan, thus, it would be naïve to expect better American-Soviet relations in case he was still a President-elect. After the end of the campaign and Reagan's victory, Reagan and his entourage were called "the most reactionary forces of American imperialism" in the works of Soviet scholars (Paskchalnyi, 1984).

Foreign electoral interference is now one of the most widespread methods through which Russia seeks to gain control over different countries. Russian interference in the 2016 US Presidential Election (Report, 2019) or Russian influence on the BREXIT process (Debate pack, 2017) are the most discussed examples. Another case is the 2017 French presidential election. There was a coordinated attempt to undermine Macron's candidacy, through: (1) a disinformation campaign consisting of rumors, fake news, and even forged documents (Macron inter alia was presented as a "gay," as a "US agent," as a "puppet" of rich bankers and globalists); (2) a hacker attack targeting the computers of his campaign staff; (3) a leak - 15 GB of stolen data, including 21,075 emails, released on Friday, May 5, 2017 - just two days before the second and final round of the presidential election. This leak was promoted on Twitter by an army of trolls and fake accounts (bots) with the hashtag \#MacronLeaks, even though none of the leaked docu- 
ments actually came from Macron, only various sources related to him. The hashtag was thus spread first by those disseminating the leak, then by those criticizing it, appearing in almost half a million tweets in twenty-four hours. Detailed analysis of this case as well as finding out who orchestrated the affair is presented in the Atlantic Council's paper "The 'Macron Leaks' Operation: A Post-Mortem" (Vilmer, 2019).

2019 European Parliament election faced intervention as well. The intervention methods are described in the AVAAZ report (Far right networks, 2019).

\section{Clandestine broadcasting}

Clandestine radio broadcasting is broadcasting in the language of the target audience from a station that does not admit its origin of transmission or which attempts to mislead listeners about its origin. Radio Ba Yi, established in 1979 and broadcasting in the Mandarin language for China, or the National Voice of Iran, established in 1959 and broadcasting in Persian on the territory of Iran, are the noticeable Cold War examples (Foreign Affairs Note, 1982).

Today, functions of clandestine broadcasting are performed mostly by social networks (especially YouTube streaming in other social networks, Internet radio). Ukraine nowadays is facing problems with clandestine broadcasting, which is mostly due to non-sanctioned use of Ukrainian telecommunications for establishing illegal broadcasting in "new republics". In particular, the information activity of Donetsk/ Luhansk "People's Republics" started with takeovers of TV centers, networks and TV towers for further broadcasting of their information programs on the occupied territories. In its own way, this can be interpreted as "clandestine broadcasting" since $\underline{d e-f a c t o}$ is non-sanctioned, and de-jure is also illegal. Besides, both territorial groups of insurgents are quite active in social networks and also have YouTube channels for news broadcasting.

\section{Agents of influence: political figures}

Specific examples of "active measures" were presented in the case of Japan where the defector and former KGB officer S. Levchenko used to work for quite a long time. In particular, he provided evidence that KGB had over 200 recruited agents in Japan in 1975-1979. Many were used for anti-American "active measures" at one time or another. These agents included journalists, members of parliament, a former cabinet minister, and leaders of Japanese political parties. Namely, during the 1970s, the KGB heavily influenced the political platform of the Japanese Socialist Party: 10 of the party's high-ranking members were Soviet agents of influence. Another example of Soviet influence in Japan was the establishment of a parliamentary group to promote Japanese-Soviet political and economic cooperation. A Soviet agent, who was a parliament member, helped to found this group, and the KGB funded its staff salaries and monthly magazine publishing (USSR monthly review, 1983). 
This practice is ongoing today. For example, a number of former heads of Ukrainian law enforcement agencies until 2014 had close dubious ties with Russia and its law enforcement agencies. O. Yakymenko, who headed the Security Service of Ukraine from 2013 to 2014, resigned from the Armed Forces of the Russian Federation only in 1998. Former Minister of Defense D. Salamatin also lived and worked in Russia until 1999, and under his leadership, a number of important military contracts were terminated by Ukrainian defense companies. In 2020, Ukrainian law enforcement agencies served him in absentia with treason charges. Another form of indirect influence on Ukrainian political reality is the work of American political technologist Paul Manafort, who has long been an adviser to former Ukrainian President Viktor Yanukovych. At the same time, all operational activities on his behalf on the territory of Ukraine were carried out by his colleague K. Kilimnik, who is tied with the Russian secret services.

Upon the outbreak of hostilities in Eastern Ukraine, all of them left the country and moved to Russia's territory. Their activity at leaders positions (in particular, administrative decisions that can be interpreted as undermining defense capability of the state and its ability to resist foreign influence) remains a matter of debate today, and experts see them as deliberate destruction of the country's defense capability (In other country's interests..., 2018). The Russian Federation supports intensive relevant activities in Europe. In particular, French researchers (for example, Vaissie, 2016) have identified entirely Russian influence networks in France.

\section{Forgeries}

In 1983, the CIA prepared a report titled "Alleged KKK death threats to third world Olympic athletes: a Soviet active measure." The situation preceding this report briefly goes as follows:

The National Olympic Committees of eleven Asian and African countries received letters threatening the lives of their Olympic athletes. The letters, allegedly sent from the United States by the Ku Klux Klan, were extremely racist and violent in tone. The CIA believed the letters were forgeries produced and disseminated by the Soviet Union in order to bolster Moscow's claim that athletes' security cannot be guaranteed at the Olympics, to reduce Third World participation at the L. A. Games, and to discredit the United States.

This conclusion was supported by the following facts: the letters did not seem to have been written by a native English speaker; the letters spelled "Ku Klux Klan" with a hyphen between the first two words, a structure not used in English; the story about the letters was immediately picked up by the Soviet media; the letters were mailed to the correct addresses of National Olympic Committees, which included post office box numbers in some cases; none of the pro-Soviet African or Asian nations boycotting the Olympics received such a threatening letter (Report KKK, 1984).

In 2015, the Swedish Institute of International Affairs released a paper "Russia's strategy for influence through public diplomacy and active measures: the Swedish case" (Kragh, Åsberg, 2017). Among the analyzed influence activities there was a political use of forgeries. 
For example, a forgery appeared as a letter signed by Tora Holst, head of the International Public Prosecution Office in Stockholm. It was uploaded to CNN's Istory website by the social media account 'doubtingsteven' on 2 September 2015, and later broadcast on Russian state television and pro-Kremlin media (Doubtingsteven, 2015). The letter addressed to Oleksiy Pokotylo at the 'Head Department for National Security and Defence Affairs' in Ukraine confirms an investigation regarding war crimes committed by a Swedish citizen in Ukraine and rejects a 'request' from Ukrainian authorities that the case should be dismissed (Nygårds, 2015).

This letter also bears the marks of a forgery including factual mistakes. The letter purports to be sent from the International Public Prosecution Office but carries the official letterhead of the Swedish government; Pokotylo is not head of the 'Head Department for National Security and Defence Affairs,' but deputy head of the 'Department of National Security with the Presidential Administration.' Furthermore, Swedish prosecutors do not usually receive nor would they reply to, requests from a foreign government. It is also doubtful that a prosecutor in the Swedish legal system would apply expressions such as 'unquestionable guilt', nor that the 'national interests of Ukraine' would be considered to the extent that a court would grant Ukrainian authorities 'access to every document' or conduct its trial 'behind closed doors' since the Swedish legal system explicitly prohibits the use of secret trials and evidence presented to the court is public.

\section{Disinformation}

A classic example of the Cold War misinformation is the story that HIV/AIDS was invented by the U.S. military together with the CIA (Boghardt, 2009). Moscow tried several times to launch this fake from various sources. Most often, the fakes spread by the Kremlin did not come from Soviet publications, but from various Western, quite marginal ones, or from the publications of Third World countries. In such a way, in July 1983, the Indian newspaper Patriot published an article in the first column titled "AIDS Attacks India: A Mystical Disease Caused by US Experiments," which was essentially the publication of an anonymous letter sent to the editorial office by unnamed "well-known American scientists and anthropologists." The letter claimed that AIDS was invented by the U.S. military as part of a biological weapons development program. Already at that stage, there were suspicions that KGB experts had something to do with the letter, as the specific argument of the letter was based on the statements about the development of biological weapons in the United States, which were actively disseminated by the USSR. Despite the efforts of Soviet intelligence then, the topic fell flat. But already in 1985, the Soviet machine of "active measures" worked at full strength in this direction. Initially, this article was reprinted by the Soviet newspaper "Literaturnaya Gazeta," and from there it moved to TASS materials. After that, Soviet-friendly intelligence, including East Germany, was involved in spreading the narrative. The latter provided a "scientific basis" for this misinformation, involving German Dr. Jacob Seagal, who, using his authority in the scientific world, managed to mix truth and fiction in his materials, 
obtaining a pseudo-scientific product that later spread widely in the West. Interviews with J. Seagal began to appear in the Western media. In 1986, this topic appeared on the central page of one of the British tabloids, and later - in the quite respectable Sunday Express and Daily Telegraph. According to experts, by the end of 1987, this misinformation was already spreading in 80 countries, appearing on the pages of over 200 periodicals published in 25 languages (Worldwide active measures, 1987). For its part, the KGB helped to ensure that this information was actively covered in African countries, as they were a space of constant confrontation with the United States. Numerous roundtables on the subject were sponsored, regular quasi-"investigations" and "exposures" were published, and calls for "investigations into the criminal activities of the U.S. military and government" were circulated. The Soviet Union is long gone, but a 2005 study found that nearly half of African Americans believed that AIDS was artificial.

Unlike the Cold War period, the disinformation of the modern period is not based on one version but exploits multi-versions. An example of such an approach is disinformation about the coronavirus: along with the COVID-19 vaccine, people will be implanted with chips; the epidemic is not really so terrible, it is possible and necessary to attend churches; the world's elites have developed this coronavirus to strengthen management control in countries; COVID-19 was created by pharmacological campaigns to increase profits. Here are some examples of common narratives from January 2020.

The European Commission's chief spokesperson on foreign and security policy Peter Stano said there had been an increase in disinformation from Russia Russia, providers based in the country and those with links to pro-Kremlin sources since the outbreak (Do Russian media, 2020).

The internal document of European External Action Service dated March 16 said that the Russian campaign in pushing fake news online in English, Spanish, Italian, German and French, uses contradictory, confusing and malicious reports to make it harder for the EU to communicate its response to the pandemic. "The overarching aim of Kremlin disinformation is to aggravate the public health crisis in Western countries...in line with the Kremlin's broader strategy of attempting to subvert European societies," the document reads (Russia deploying, 2020).

The official report "Tackling COVID-19 disinformation - Getting the facts right" was published in June 2020 (Joint Communication, 2020).

\section{“ACTIVE MEASURES” OF THE USSR AND RUSSIA'S HYBRID WAR: DETERMINING COMMON FEATURES}

In its standoff against the Russian Federation, Ukraine is facing nearly all of the abovementioned methods. At the same time, the current situation is a far cry. Today, the emphasis on the use of cyber and psychological methods as well as the active use of other most actual trends of the global world development (mostly related to the information revolution, spread of military technologies and globalization) is supplemented by military aggression. On the one hand, this aggression has become the direct 
consequence of using "active measures" on the territory of our country for many years, if not decades; and on the other, these "active measures" are still being applied against Ukraine till now alongside military operations.

The very fact of military factor availability "converts" the implementation of "active measures" into the act of hybrid war. While the beginning of this hybrid war confirms the lack of capacities of the subject of influence to reach its objectives through non-military methods.

From the theoretical standpoint of the contemporary military \& political thought, the concept of "active measures" can become the basis for a proper understanding of the "hybrid war" if the latter is taken as an evolutionary development of "active measures."

We can also state that hybrid war today becomes not only the continuation of "active measures" (the next logical step in their development; their update due to changes in the external environment; or as the so-called "alternative" actions ${ }^{3}$ ) but it somehow "absorbs" them at the same time placing the military factor on the top, which is implemented through the following actions:

- Direct military aid to the insurgents, the facts of which are officially denied by the side providing this aid;

- Providing resources (financial, economic, diplomatic, military and administrative) to the groups directly waging military aggression;

- Annexing part of the territory of another state.

Both "active measures" and hybrid war are destructive influences, subject to one common political strategic goal and plan, imposed by one state against another, or by one state against several other states. Such a strategic goal is realized through the achievement of specific aims, including cultural, ideological, energy expansion, political control, influence on the components of national stability, undermining trust to public authorities etc. These aims are the same for both the former Soviet Union and modern Russia.

Before the actual implementation of "active measures," a more general political strategic plan should be approved. For example, it may include bringing to power the controlled subjects of political influence (the agents of influence) which are supposed to adjust the general course of a country (external, economic, military, cultural etc.) in the needed direction. This would be the maximum control level. While the minimum control level in this regard would include the formation of a rather neutral perception of an aggressor by the local public opinion, with the emphasis on supposedly "friendly relations." Formation of the needed public attitude and imposing the idea that such cooperation and friendship have no reasonable alternative require the application of quite a variety of methods and tools from the "active measures" toolbox.

In our view, implementation of "active measures" is a permanent activity, especially when it comes to the states which happen to be neighbors of other states with very ambitious plans of expanding the sphere of interest and direct influence.

${ }^{3}$ Alan Malcher, for example, states that "active measures" and hybrid war are inseparable and all their elements may be used together, "separately or tailored to fit various objectives and may be culturally, religiously or politically specific for the optimum effect” (Malcher, 2016). 
Such geopolitical situation put forward the issue of the efficiency of intelligence and counterintelligence units' performance and also the question of what measures should be taken to consolidate population, what preventive measures should be applied to avoid the most aggressive "active measures" (or at least what measures can be taken to minimize the consequences). This actually implies that efforts must be taken to build a "resilient society" able to restore quickly after a destructive scenario was implemented against it.

In theory, the full implementation of "active measures" means a certain strategic political plan has been achieved. However, in real life there may be additional (pre) conditions, for example:

- If the aggressor, after obtaining the minimum-level control, decides to pursue the maximum-level control;

- If the state which is the object of aggression is able to demonstrate rather efficient and persuasive counteraction, however, the latter is not strong enough to declare obvious win in the standoff;

- In case the policy of "soft power" has failed, hybrid war becomes the only way to reach the strategic political aim. In a certain sense, the object of influence is forced to wage a hybrid war because this is the most logical continuation of "active measures" if they are not efficient enough. The key task of "active measures" at the stage of transition to hybrid warfare would be creating an artificial trigger for open military actions.

Using the pre-arranged resource, the subject of influence launches limited but direct military intervention - this marks the beginning of a hybrid war. Major efforts are concentrated on the general support of the insurgents, and this support may have many aspects. First of all, this is direct military aid through arms supply and sending the qualified staff, mostly from among special forces officers. Economic support is also provided ranging from direct financial inflows to quasi-humanitarian aid.

One of the necessary preconditions for initiating a hybrid war is the overall negative socioeconomic and/or political situation in the country against which the aggression is committed. One important factor which makes hybrid war possible is the weakness of internal military force of the object of influence, including outdate equipment, the unpreparedness of the local army to real tasks, the disinclination of military leaders to face real war situations.

Taking into account all of the above, we suggest the following classification of methods used during a hybrid war (see Figure 1).

Therefore, we can state that today Ukraine is experiencing the hybrid war as a special form of standoff and a combination of "active measures" being used against it alongside military aggression.

Hybridism of this ongoing conflict has been determined by the Pentagon analysts in the early 2000 and later found its full manifestation in Ukraine. Combination of various forces and means employed in the Donetsk and Luhansk oblasts includes: support for separatists, sending own special forces and Russian regulars with advanced military capabilities, electronic warfare, drones, rocket launchers; employment of political repressions, control over food supplies and suppression of local employment and economic security to control the local population. Moreover, the accidental catastrophic 
Figure 1. Methods of hybrid warfare

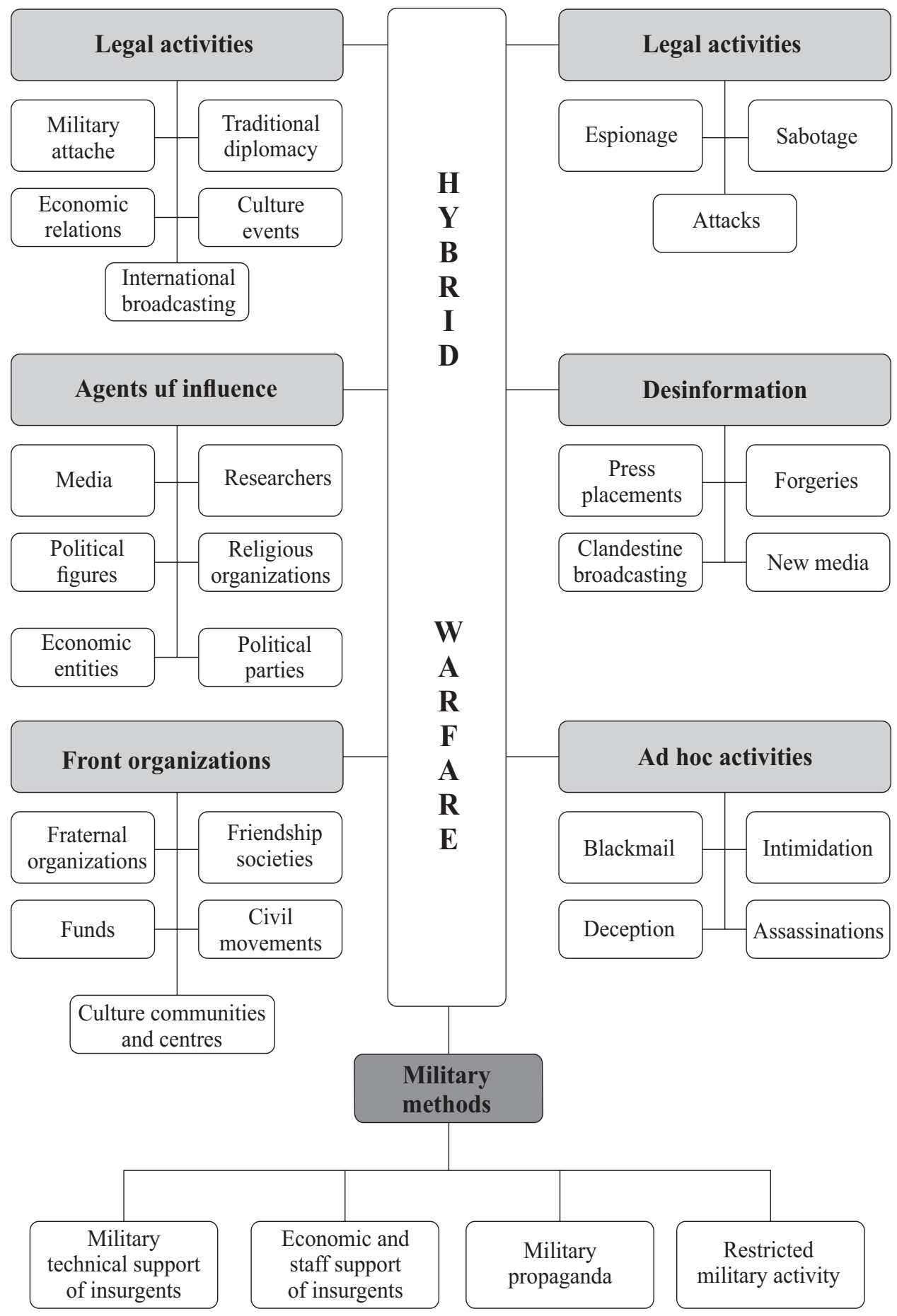

Source: Own work authors. 
act of killing 217 passengers aboard $\mathrm{MH}-17$ is also represented as an additional hybrid threat (Hearing, 2017).

It would be also fair and feasible to consider Ukrainian local conflict in a wider context of the "world hybrid war," that is, Russia's waging hybrid war against the Western world as such (Horbulin, 2017). Hybrid war as a form of Russia's rather aggressive solving of its geopolitical tasks is not limited to Ukrainian territories, it tends to develop further, and its forms become increasingly diverse, thus spreading hybrid warfare on new territories (Horbulin, 2016). Military intervention in Syria and incidents with Turkey are additional evidence confirming that Russian hybrid warfare is quickly becoming global, and the aggressor's attempts to guarantee itself the maximum control may have the most negative consequences for the global order as such. Moreover, the less Western states react to Russia's aggressive behavior - the more probable this scenario is. On the regional level of the "Western world" (that is, Europe and the U.S.) the standoff still remains on the level of "active measures" only, however, even in these rather distanced countries Russia's "active measures" become more and more aggressive.

Further conceptualization of the notion of "hybrid warfare" taking into account the notion of "active measures" would allow optimizing (and systematizing) the mechanisms which can be applied to counter the aggressor, since this would enable to consolidate separate actions and steps from various fields of activity into one common, logically constructed chain of actions.

\section{CONCLUSIONS}

Vigorous subversive activities today (as well as in Soviet times) remain an important component of Russia's foreign policy strategy. Although the methods of such activities have been partially modernized in specific forms of implementation, they remain largely stable in essence.

In our opinion, "active measures" stand for the activities aimed at the achievement of external and internal political aims of the state as the subject of influence; these activities are implemented to exert negative influence on the public opinion in the state which is the object of influence and to change the policies and activities of the government in this state, erode trust to its political leaders and institutions as well as to disorient the global public opinion in its assessments of this state's policies and activities.

The essence of "active measures" can be described by the formula: goal plus method, where the method means the specific actions taken by the performer. "Classical" methods within "active measures" may include: spreading disinformation (via publishing materials in mass media, forging documents and/or clandestine broadcasting), use of front organizations (societies of friendship, civil movements), using the agents of influence (in media, science and politics), illegal activities (deception, blackmailing, intimidation, political assassinations etc.).

Methods of contemporary "active measures" and examples of their implementation are given in the table below. 
Methods of contemporary "active measures" and examples of their implementation

\begin{tabular}{|c|c|c|}
\hline \multirow{2}{*}{$\begin{array}{l}\text { Method of "active } \\
\text { measures"' }\end{array}$} & \multicolumn{2}{|c|}{ Examples / cases } \\
\hline & Cold War & Nowdays \\
\hline 1 & 2 & 3 \\
\hline $\begin{array}{l}\text { LEGAL ACTIVITIES, includ- } \\
\text { ing Military attaché, Culture } \\
\text { events }\end{array}$ & + & + \\
\hline Economic relations & $\begin{array}{l}\text { 1947. A large-scale USSR cam- } \\
\text { paign against General Franco was } \\
\text { conducted inter alia through the } \\
\text { breaking of commercial relations } \\
\text { between Spain and other countries. }\end{array}$ & $\begin{array}{l}\text { Russia - Ukraine, Belarus Georgia gas } \\
\text { disputes }\end{array}$ \\
\hline Traditional diplomacy & \multicolumn{2}{|c|}{$\begin{array}{l}\text { Using diplomatic posts as a cover for the activities of spies, evidenced in } \\
\text { particular by their revelations }\end{array}$} \\
\hline & $\begin{array}{l}\text { In } 1971 \text {, British Prime Minister Ed- } \\
\text { ward Heath expelled } 90 \text { spies from } \\
\text { the Soviet embassy and blocked the } \\
\text { return of } 15 \text { more to Britain. They } \\
\text { learned about them from a high- } \\
\text { ranking KGB defector. }\end{array}$ & $\begin{array}{l}\text { In } 2018 \text {, due to the poisoning of Skri- } \\
\text { pals, } 23 \text { agents working under diplo- } \\
\text { matic cover were expelled from Lon- } \\
\text { don. Britain's friends and partners took } \\
\text { similar steps. }\end{array}$ \\
\hline International broadcasting & "Radio Moscow" World Service & RT та Sputnik \\
\hline AGENTS OF INFLUENCE & + & + \\
\hline Media & $\begin{array}{l}\text { Creating overt and covert own me- } \\
\text { dia abroad or recruiting individual } \\
\text { journalists (Jean) to form the re- } \\
\text { quired agenda }\end{array}$ & Developing RT and Sputnik network \\
\hline Researchers & Jakob Segal & $\begin{array}{l}\text { Director of the Institute of World Econ- } \\
\text { omy and International Relations of } \\
\text { the National Academy of Sciences of } \\
\text { Ukraine Yuriy Pakhomov stated in } 2011 \\
\text { that Ukraine is a failed state, connecting } \\
\text { this with the genetics of the Ukrainian } \\
\text { ethnic group. }\end{array}$ \\
\hline Political figures & $\begin{array}{l}\text { High-ranking members of the Japa- } \\
\text { nese Socialist Party }\end{array}$ & $\begin{array}{l}\text { Former Head of the Security Service of } \\
\text { Ukraine O. Yakymenko, former Minister } \\
\text { of Defense of Ukraine D. Salamatin. }\end{array}$ \\
\hline Religious organizations & Russian Orthodox Church (ROC) & $\begin{array}{l}\text { Russian Orthodox Church, participation } \\
\text { of UOC-MP clergy in military opera- } \\
\text { tions in Donbas. }\end{array}$ \\
\hline Economic entities & - & $\begin{array}{l}\text { The overall number of Russia's eco- } \\
\text { nomic agents of influence today is big- } \\
\text { ger than in the other spheres of influ- } \\
\text { ence: since } 2007-2008 \text { Russia has been } \\
\text { actively attracting foreign companies to } \\
\text { enter Russian internal markets, luring } \\
\text { them with potential hyper-profits and } \\
\text { vast opportunities due to rather relaxed } \\
\text { and flexible legislation. }\end{array}$ \\
\hline Political parties & Communist Party & Far-right, far-left, populists \\
\hline $\begin{array}{l}\text { FRONT ORGANIZATIONS, } \\
\text { including Fraternal organiza- } \\
\text { tions, Friendship societies, } \\
\text { Funds, }\end{array}$ & & \\
\hline Civil movements & $\begin{array}{l}\text { The World Peace Council, the } \\
\text { World Council of Churches }\end{array}$ & YESCalifornia \\
\hline
\end{tabular}




\begin{tabular}{|c|c|c|}
\hline 1 & 2 & 3 \\
\hline $\begin{array}{l}\text { Culture communities and cen- } \\
\text { ters }\end{array}$ & & Russkiy Mir Foundation \\
\hline $\begin{array}{l}\text { DISINFORMATION, includ- } \\
\text { ing Press placements }\end{array}$ & AIDS & COVID-19 \\
\hline Forgeries & $\begin{array}{l}\text { "Ku Klux Klan" letters to third } \\
\text {-world Olympic athletes }\end{array}$ & $\begin{array}{l}\text { Letter of the head of the International } \\
\text { Public Prosecution Office in Stockholm }\end{array}$ \\
\hline Clandestine broadcasting & Radio Ba Yi, National Voice of Iran & $\begin{array}{l}\text { YouTube, streaming in other social net- } \\
\text { works; } \\
\text { use of Ukrainian telecommunications in } \\
\text { Donetsk/Luhansk "People's Republics" }\end{array}$ \\
\hline New media & - & + \\
\hline $\begin{array}{l}\text { AD HOC ACTIVITIES, in- } \\
\text { cluding Blackmail, Deception, } \\
\text { Intimidation }\end{array}$ & + & + \\
\hline Assassinations & Leon Trotsky & Alexander Litvinenko \\
\hline CYBER ACTIVITIES & - & + \\
\hline Espionage & & $\begin{array}{l}\text { Stealing documents in order to further } \\
\text { disseminate them and influence public } \\
\text { opinion. For example, MacronLeaks. }\end{array}$ \\
\hline Sabotage & & $\begin{array}{l}\text { In 2015, Prykarpattyaoblenerho was at- } \\
\text { tacked, in } 2016 \text { - the State Treasury of } \\
\text { Ukraine and the Ministry of Finance of } \\
\text { Ukraine, and in } 2018 \text { the NotPetya virus } \\
\text { raged. The goal was not to disrupt the } \\
\text { system but to cause social or political } \\
\text { chaos. }\end{array}$ \\
\hline Attacks & & $\begin{array}{l}\text { The goal is to disrupt the system. An ex- } \\
\text { ample is the attacks on the "Elections" } \\
\text { information system during the } 2014 \\
\text { presidential election in Ukraine. }\end{array}$ \\
\hline
\end{tabular}

Source: Own work authors.

A comparison of the methods suggests a certain "heredity" of modern actions taken by the Russian Federation to achieve its strategic goals and the "active measures" of the USSR during the Cold War. In our opinion, the modern hybrid war waged by the Russian Federation against democracies, especially Western ones, is a combination of "modernized" methods of "active measures" with military methods. The common strategic goal of such hybrid actions is the destruction of Western democracies and the depreciation of Western values in general.

\section{REFERENCES}

Abrams S. (2016), Beyond Propaganda: Soviet Active Measures in Putin's Russia, "Connections", No. 1.

Background Briefing (1985), Spanish-Soviet relations, Background Briefing for the DCI, October 15, "General CIA Records", https://www.cia.gov/library/readingroom/docs/CIA-RDP86T01017R000404410001-7.pdf (11.03.2020).

Badanin R. (2019), Master and Chef. How Evgeny Prigozhin led the Russian offensive in Africa, "Proekt", https://www.proekt.media/en/article/evgeny-prigozhin-africa/ (07.07.2020). 
Bass C. (1999), Building Castles on Sand: Underestimating the Tide of Information Operations, "Airpower Journal", Vol. XIII, No. 2

Boghardt T. (2009), Operation INFEKTION. Soviet Bloc Intelligence and Its AIDS Disinformation Campaign, "Studies in Intelligence", Vol. 53, No. 4, https://www.cia.gov/library/center-for-the-study-of-intelligence/csi-publications/csi-studies/studies/vol53no4/pdf/U-\%20 Boghardt-AIDS-Made\%20in\%20the\%20USA-17Dec.pdf (07.07.2020).

Darczewska J., Żochowski P. (2017), Active measures. Russia's key export, https://www.osw.waw. pl/en/publikacje/point-view/2017-05-30/active-measures-russias-key-export (07.07.2020).

Debate pack (2017), Russian interference in UK politics and society, 2017, December, https:// researchbriefings.files.parliament.uk/documents/CDP-2017-0255/CDP-2017-0255.pdf (07.07.2020).

Definitions for terms (1982), Definitions for terms of reference and outline for NSSD 2/82, 1982, April 28, "General CIA Records", https://www.cia.gov/library/readingroom/docs/CIA-RDP86B01123R000100070012-0.pdf(11.03.2020).

Do Russian media... (2020), Do Russian media spread Covid-19 disinformation?, EU Debates, 2020, March, https://www.youtube.com/watch?v=F0tdog2tRh8 (07.07.2020).

Doubtingsteven (2015), Sweden has Refused to Disclose Information on Military Crimes of the Ukrainian Army, 2 Dec. 2015, http://doubtingsteven.blogspot.se/2015/09/sweden-has-refused-to-disclose.html (11.03.2020).

Far right networks (2019), Report: Far right networks of deception, https://secure.avaaz.org/campaign/en/disinfo_network_report/ (11.03.2020).

Foreign Affairs Note (1982), Foreign Affairs Note: Communist Clandestine Broadcasting, December 1982, https://archive.org/stream/CommunistClandestineBroadcasting/CommunistClandestineBroadcasting_djvu.txt (11.03.2020).

Joint Communication... (2020), Joint Communication to the European Paliament, The European Council, The Council, The European Economic and Social Committee and the Committee of the Regions "Tackling COVID-19 disinformation - Getting the facts right", 2020 June, https://ec.europa.eu/info/sites/info/files/communication-tackling-covid-19-disinformationgetting-facts-right_en.pdf (07.07.2020).

Hearing (2017), The Evolution of Hybrid Warfare and Key Challenges, U.S. Government Publishing Office, https://www.govinfo.gov/content/pkg/CHRG-115hhrg25088/pdf/CHRG115hhrg25088.pdf (11.03.2020).

Hohol K. H. (1988), Soviet Communication: Active Measures and Information Management, "The University of Alberta", Canada.

Horbulin V. (2016), Hibrydna viyna: vse tilky pochynayetsya... [Hybrid war: this is only a beginning...], "Dzerkalo tyzhnya", March 25.

Horbulin V. (2017), Svitova gibridna viyna: ukraiinskyi front: monographiya [World hybrid war: Ukrainian front: Monograph], (ed.) V. P. Horbulin, Kyiv, National Institute for Strategic Studies.

HPSCI briefing (1983), HPSCI briefing 20 September 1983, "General CIA Records", https://www. cia.gov/library/readingroom/docs/CIA-RDP85B00263R000200170005-9.pdf (11.03.2020).

Kragh M., Åsberg S. (2017), Russia's strategy for influence through public diplomacy and active measures: the Swedish case, https://www.tandfonline.com/doi/abs/10.1080/01402390.2016 .1273830 ? journalCode $=\mathrm{fj}(11.03 .2020)$.

Lichenstein C. (1985), Soviet Espionage: Using the U.N. Against the U.S., Report, 1985, September 9, http://www.heritage.org/homeland-security/report/soviet-espionage-using-the-un-againstthe-us (11.03.2020). 
Malcher A. (2016), KGB Active Measures and Russian Hybrid Warfare: a brief comparison, https:// www.linkedin.com/pulse/kgb-active-measures-russian-hybrid-warfare-brief-alan-malcherma (11.03.2020).

Manfred R. (1984), "How Moscow Meddles in the West's Elections," https://www.heritage.org/election-integrity/report/how-moscow-meddles-the-wests-elections (11.03.2020).

Memo (1984), Study proposals in your 4 September 1984 memo, October 11, "General CIA Records", https://www.cia.gov/library/readingroom/docs/CIA-RDP86M00886R000600100001-7.pdf (11.03.2020).

Memorandum (1985), Memorandum from G. Kolt about Hoover Institution conference on Soviet active measures in Western Europe, June 10, "General CIA Records", https://www.cia.gov/ library/readingroom/docs/CIA-RDP87R00529R000100020015-6.pdf(11.03.2020).

NSSD 2/82 (1982), Detecting and Countering the Foreign Intelligence Threat to the United States, National Security Study, Directive Number 2-82, February 16, https://archive.org/details/NSSD282DetectingAndCounteringTheForeignIntelligenceThreatToTheUS (11.03.2020).

Nygårds O. (2015), Fake Swedish Letter on Russian TV: "Unknown Author" [Falskt svenskt brev i rysk tv: 'Okänd avsändare'], "Svenska Dagbladet", 13 Sept. 2015, http://www.svd.se/falskt-svenskt-brev-i-rysktv-okand-avsandare (11.03.2020).

Osnos E., Remnick D., Yaffa J. (2017), "Trump, Putin, and the New Cold War: What lay behind Russia's interference in the 2016 election - and what lies ahead?," "The New Yorker", 2017, March 6.

Pashalniy P. (1984), Borba Komunisticheskoy partii SSHA protiv agressivnoy politiki amerikanskogo imperialisma (1976-1980) [The struggle of the Communist Party of the USA against the aggressive policy of American imperialism (1976-1980)], Theses for PhD in history, Moskow.

Pilon J. (1986), At the U.N., Soviet Fronts Pose As Nongovernmental Organizations, "The Heritage Foundation", http://www.heritage.org/global-politics/report/the-un-soviet-fronts-posenongovernmental-organizations (11.03.2020).

Report (1982), Soviet military power, First ed. 1981, September; Second ed. 1983, March, "General CIA Records", https://www.cia.gov/library/readingroom/docs/CIA-RDP85M00364R001101610018-6.pdf(11.03.2020).

Report... (2019), Report On The Investigation Into Russian Interference In The 2016 Presidential Election, Volume I of II, 2019, March, https://www.justice.gov/storage/report.pdf (07.07.2020).

Report KKK (1984), Alleged KKK death threats to third world Olympic athletes: a Soviet active measure, 1984, July 17, "General CIA Records", https://www.cia.gov/library/readingroom/ docs/CIA-RDP85T00287R001400750001-6.pdf(11.03.2020).

Russia deploying... (2020), Russia deploying coronavirus disinformation to sow panic in West, EU document says, Reuters, 2020, March, https:/www.reuters.com/article/us-health-coronavirus-disinformation/russia-deploying-coronavirus-disinformation-to-sow-panic-in-west-eudocument-says-idUSKBN21518F (07.07.2020).

Special Report (1981), Soviet active measures: forgery, disinformation, political operations, Special Report No. 88, 1981, October, "General CIA Records", https://www.cia.gov/library/readingroom/docs/CIA-RDP84B00274R000100040004-8.pdf (11.03.2020).

Sulc L. B. (1985a), Active measures, quiet war and two socialist revolutions, The Nathan Hale Institute, "General CIA Records", https://www.cia.gov/library/readingroom/docs/CIA-RDP9000806R000200720008-2.pdf (11.03.2020).

Sulc L.B.(1985b), The KGB and the United Nations, The Nathan Hale Institute, "General CIARecords", https:// www.cia.gov/library/readingroom/docs/CIA-RDP90-00806R000100470001-8.pdf (11.03.2020). 
Telegram (1946), Telegram, George Kennan to George Marshall [“Long Telegram”], February 22, 1946, Harry S. Truman Administration File, Elsey Papers, https://www.marshallfoundation.org/marshall/the-marshall-plan/interviews-transcripts/george-f-kennan-strategic-background/ (11.03.2020).

USSR monthly review (1983), USSR monthly review, 1983, April, "General CIA Records", https://www.cia.gov/library/readingroom/docs/CIA-RDP84T01083R000100050002-2.pdf (11.03.2020).

Ustav Kommunisticheskogo Internastionala [The Statute of the Communist International], Der Zweite Kongress der Kommunistischen Internationale. Protokoll der Verhandlungen vom 19. Juli in Petrograd und vom 23. Juli bis 7, August 1920 in Moskau (Hamburg, 1921).

Vaissie C. (2016), Les Réseaux du Kremlin en France.

Whittle S. (2015), "Conquest from within": a comparative analysis between Soviet active measures and United States unconventional warfare doctrine, United States Military Academy, West Point (New York).

Worldwide active measures... (1987), Worldwide active measures and propaganda alert, 1987 November, "General CIA Records", https://www.cia.gov/library/readingroom/docs/CIA-RDP88T00986R000100040002-8.pdf (07.07.2020).

Young B. (1987), Soviet active measures in the United States - an updated report by the FBI, Congressional record - Extensions of remarks, "General CIA Records", https://www.cia.gov/ library/readingroom/docs/CIA-RDP11M01338R000400470089-2.pdf (11.03.2020).

V interesah inshoii derzhavy... (2018), V interesah inshoii derzhavy: problemi vyyavlennya ta protydii ahentam vplyvu [In other country's interests: the problems of detection and countering for agents of influence], D. Dubov, I. Koretska, Kyiv, https://niss.gov.ua/sites/default/ files/2019-05/Dopovid_Agenty_vplyvu.pdf (11.03.2020).

Vilmer J.-B. (2019), The "Macron Leaks" Operation: A Post-Mortem, Atlantic Council, 2019, June, https://www.atlanticcouncil.org/wp-content/uploads/2019/06/The_Macron_Leaks_Operation-A_Post-Mortem.pdf (07.07.2020).

Vuys M. (2016), «Aktivnie meropriyatia» rosiyskih cpecsluzhb [“Active measures” of Russian special services] "InoSMI.ru”, http://inosmi.ru/politic/20160728/237359416.html (11.03.2020).

\begin{abstract}
The growth and dissemination of Russia's propaganda have become a serious threat in recent years. But these efforts of Russia are not new, they have a basis in the past - known as "active measures." Therefore, the problem of detecting and counteracting these "active measures," first and foremost, is that there is no commonly accepted definition of the term. Therefore, the authors addressed the specific problem of the definition of "active measures." The authors found that all "active measures" were subordinated to a single political strategic idea, and this idea was carried out by various methods. The authors are convinced that any classification of current "active measures" should be based on the methods detected. In order to identify these methods, the scheme of "active measures," suggested by S. K. Whittle, is used. At the same time, his scheme has been supplemented, and the relevant cases for the application of different methods of "active measures" are given. An attempt is made to compare the methods of applying "active measures" with current aspects of the hybrid war of the Russian Federation, in particular in Ukraine.
\end{abstract}

Keywords: active measures, influence operations, Russia, USA, hybrid war, Cold War 


\section{„ŚRODKI AKTYWNE” STOSOWANE PRZEZ ZSRR PRZECIWKO USA: STARE ZAGRYWKI SOWIETÓW W NOWEJ RZECZYWISTOŚCI GEOPOLITYCZNEJ}

\section{STRESZCZENIE}

Rozwój i rozpowszechnianie rosyjskiej propagandy stało się w ostatnich latach poważnym zagrożeniem. Rosyjskie wysiłki nie są jednak niczym nowym i opierają się na stosowanych w przeszłości tak zwanych ,środkach aktywnych”. Problem z wykryciem i przeciwdziałaniem „środkom aktywnym” polega przede wszystkim na braku powszechnie przyjętej definicji tego terminu. Dlatego autorzy poruszyli szczególny problem definicji „środków aktywnych”. Stwierdzili, że wszystkie „środki aktywne” podporządkowano jednej politycznej idei strategicznej realizowanej różnymi metodami. Autorzy są przekonani, że klasyfikacja aktualnie stosowanych „środków aktywnych” powinna opierać się na wykrytych metodach. W celu identyfikacji tych metod zastosowano schemat „środków aktywnych” zaproponowany przez S. K. Whittle'a. Schemat ten równocześnie uzupełniono i wskazano stosowne przypadki różnych metod stosowania ,środków aktywnych”. Podjęto również próbę porównania metod stosowania ,środków aktywnych" z aktualnymi aspektami wojny hybrydowej Federacji Rosyjskiej, zwłaszcza na Ukrainie.

Słowa kluczowe: środki aktywne, operacje wywierania wpływu, Rosja, USA, wojna hybrydowa, zimna wojna 
